\title{
Potential Adoption and Commercial Introduction of GM Crops in Finland: A Case Study on Potato
}

\author{
Jyrki Niemi \\ Natural Resources Institute Finland - Luke \\ Latokartanonkaari 9 \\ FI-00790 Helsinki \\ Jussi Tuomisto \\ TanzaniceAgrofoods Company ltd. \\ Hopiantie 51 \\ FI-51300 Kurikka
}

\begin{abstract}
This paper analyses the possible adoption and commercial introduction of genetically modified (GM) crops in Finland. It is divided into two main parts. First and foremost, based on the available literature, the economic and policy factors which influence the rate of adoption and diffusion of GM technology in agriculture are examined. Secondly, the potato is used as a case study to provide further insights into economic and strategic issues plus the implications of adopting GM technology within the Finnish agri-food chain. The case study is based on interviews with key players involved in farming, processing, trade, and the administration of the production of potato.The results suggest that GM technology will not alter the basic structure of agri-food industry, but will create changes in the cost and benefit distribution. In addition, an increased use of contractual arrangements will lead to greater vertical integration and co-ordination in the value chain of potato.
\end{abstract}

Keywords: biotechnology, technology adoption, genetically modified crops, potato, food chain, regulations

\section{Introduction}

Gene technology is not used in the production of Finnish foodstuffs, at the moment, and genetically modified (GM) plant varieties are not farmed for commercial use. The cultivation of GM plants is possible only for research purposes. The situation is somewhat similar in the rest of the Europe. Due to several factors - including national bans-European farmers have not adopted GM crops on a large scale, with the notable exception of Spain, where Bt maize now covers about one-third of the total maize area (Kathage et al., 2016). People from Finland tend to be slightly less negative to GM food in comparison to many other European countries (Eriksson et. al., 2018).

This paper analyses the possible adoption and commercial introduction of GM crops in Finland. The aim of the paper is to clarify those new issues which farmers and the entire agri-food chain face with the advent of GM crops. The study shows, among other things, how different farms will be able to adopt the new technology, how contract production will affect farms, how the environment in which farms operate will change, and what the concrete pros and cons of gene technology are. These questions will be essentially analysed from the point of view of the farmer.

In order to provide further insights into economic and strategic issues plus the implications of adopting GM technology in the Finnish agri-food chain, a case study on potato has been carried out. The case study is based on interviews with key players involved in farming, processing, trade, and the administration of the production of potato. The production chain of potato is long and complex, making it a good example when illustrating e.g. the problems of segregation and identity preservation (IP). The case study focuses on the economic benefits and costs of gene technology in Finnish agriculture.

The special problems facing Finnish agriculture with respect to the GM technology have seldom been dealt in the respective subject literature. Finnish farms are generally smaller than in Central Europe and therefore may be facing a much greater challenge to capitalise on the strategic potential of the gene technology. In addition, both the northern location and climate of Finland set certain special restrictions on the use of gene technology (Niemi and Virolainen, 2002). The case study on potato is carried out through interviews with experts from all fields of the potato supply chain. The information from these interviews and literature on the subject is used to form an overall picture of the impacts of GM technology on the agri-food chain. Emphasis is put on the interaction between the development of transgenic potatoes and the restructuring of the potato chain. 


\section{Gene technology and the Finnish farm}

Finnish farms are considerably smaller than the farms in the leading agricultural countries of the EU. Equal opportunities for farms to adopt new technologies are very important for countries like Finland. If innovations are not available to every farm, a significant part of farms couldmiss out on new developments, whether they want it or not. Several studies underline that economic benefits from adopting GM technology vary widely between farmers (Bullock and Nitsi, 2001; Brookes and Barfoot, 2017; Desquilbet et al., 2002). Some argue that the ability of small businesses to adopt innovations to be weaker than that of larger businesses. Reasons for this include advantages provided by increasing returns of the scale, imperfect competition, unfavourable market structures and policies, etc. If the information costs associated with adoption are high, then an "information bias" may also exist, where large farms find it easier to adopt new technology, since they can spread the fixed cost of adoption over a larger level of production (Kinnucan et al., 1990)

As far as potato is concerned, the adoption of gene technology on smaller farms would not seem to pose a problem. There are several reasons for this. First, gene technologies available today are relatively inexpensive. All that one need is to invest in new seeds and pesticides. Copyright fees and royalties for these items will increase, of course, but not so much as to have a significant effect on the rate of adoption of new innovations. Additional costs might of course emerge, for example reason of segregation, if the construction of separate storage buildings or such is necessary, but costs will be low to start with.

Secondly, information on new technological developments and their applications is readily available to all farmers in Finland. Information on cultivation is also equally available to farmers in Finland, and the situation is unlikely to change in future. Principals in contract production give out information, since it is naturally beneficial to them. Public services are also readily available to farmers. Therefore, small farms are not at a disadvantage in terms of available information when compared to larger farms.

Furthermore, small farms are not by-passed in the marketplace. Based on interviews, partnerships with smaller farms are still interesting to contractors, and contracts are still made in spite of smaller volumes. On the other hand, geographical discrimination can occur, particularly in the case of potato farming (Tuomisto and Huitu, 2006; Tuomisto, 2007). Due to the very low price of the potato, and high logistical costs, the production of starch potatoes, for example, is concentrated on certain regions (Tuomisto and Huitu, 2006). This eliminates logistical costs from increasing too much and has already led to a certain degree of specialisation.

Another concern, which is likely to affect all farms, is the availability of suitable GM varieties (Tuomisto, 2004). With the exception of the potato, genetically modified crops cultivated in Central-Europe are usually not suitable for cultivation in Finland without further refining (Ministry of Agriculture and Forestry of Finland, 2019), owing to the fact that the large global biotechnological firms do not set out to solely develop varieties intended for Finland's boreal climate and small markets. These varieties have to be developed either as a result of domestic research and development work, or by purchasing genes and GM plants from foreign companies for use in domestic plant breeding (Salo et al., 1998). However, contract production with variety representative make easier to Finnish potato farmers purchase seed from outside Finland (Tuomisto, 2007).

The main advantages offered to farmers by GM technology would be the agronomic gains. Such benefits come in the form of yield increases, cost reductions in plant disease or pest management, improved risk management and insurance against pests etc. (Guenthner, 2017; Pietilä, 2005) Potato farming would also become technically easier. The advantages are therefore considerable. On the other hand, studies (for example, Hillyer, 1999) have shown that there are signs that contract production might become too restrictive from the farmer's point of view. In Finland, however, there is no evidence of circumstances where the autonomy of farmers has been weakened considerably as a result of contract production. It should be noted, however, that with the exception of the malt and starch industry and seed potato production contract production is relatively rare in Finland.

Overall, the interviewees were somewhat in disagreement as to the effects of gene technology on the status (e.g. autonomy) of the farmer. It was not seen as a realistic scenario that farmers would end up in a position where they are "crofters" in the service of large companies, but it was considered possible that there would be some decrease in autonomy. Some maintain that contracts erode a tradition of farmer independence in production decisions and management. On the other hand, others argue that contracts are likely to offer premiums over average market prices for agricultural commodities, greater access to new technology and inputs, and new sources of capital. Commitment to a single product was considered a bad thing if there were only one or two companies operating in the field of GM technology, but were there several companies competing freely, the position of the farmer would be better. Constraints and mandatory reporting enforced by the public sector were also seen as possible but undesirable. Most of the interviewees believed that the farmer's position would remain largely unchanged. 
As far as farmers are concerned, the length and multi-faceted nature of agri-food chains is a positive thing, as it helps distribute possible costs widely. However, the increased concentration in the seed and chemical industries due to advances in biotechnology creates new threats. An increasing inter-dependency is forming between the research/development and trade of agricultural chemicals, gene technology and basic seed production. Many chemical and pharmaceutical corporations are acquiring seed companies to obtain more control over the development and marketing of new seed varieties. Due to the high costs of research and development, only the largest and most economically stable companies are able to engage in it. Some interviewees suggest this may be undesirable to farmers, since the farmer's share of the costs usually increases in a concentrated market.

The marketing of GM varieties and products might prove a stumbling block in Finland. The attitude of both consumers and retailers toward GM products is less than enthusiastic. With some consumers reluctant to eat genetically modified organisms (GMOs), two supply channels have to be segregated (one for goods without GMOs above given tolerance level and one for goods that contain GMOs above these tolerance levels). As a result, some seed producers, farmers, handlers and food processors are striving to preserve the identity of non-GM goods by keeping them segregated from GM goods, to meet demand for non-GM goods.

A dual stream of supply and marketing plus the labelling requirements for GM-derived products will lead to additional cost at all stages of the food chain in terms of setting up identity preservation (IP) management system (Punt et al., 2017). A critical factor to determine the costs will be the tolerance level for GM product inclusion in the non-GM product. Abiding to the $0.9 \%$ threshold set by the EU is expected to become increasingly difficult and costly as GM crop production increases in Europe.

\section{The potato supply chain in Finland}

The potato supply chain in Finland is a chain that consists of the different stages of production beginning with micropropagation (in vitro) and, separately, input marketsand ending at the consumer. The aim of the chain is to meet the needs of the consumer, but every participant in the chain (with the exception of the official Plant Protection Service) strives, in addition, to maximise their profits. In addition to supplying material, the chain supplies market information has needed to adjust to changes in the marketplace for better cost efficiency.

The Finnish Seed Potato Centre Ltd. - SPK - is a seed potato producing enterprise, which continues the work of former state owned institute. The tasks of the SPK are the maintenance of healthy seed material and basic seed production of the potato varieties cultivated in Finland or produced for export. In this connection, the SPK maintains a close-knit cooperation with potato growers, breeders in different countries and representatives of potato varieties in Finland. The maintenance of varieties and the production of basic strains in Finland are based on agreements with agents for different varieties. Agents can also import the varieties they represent from abroad without additional cultivation at the SPK (Tuomisto, 2007).

There are six agents for seed potato in Finland: HZPC Kantaperuna Ltd., The Finnish Seed Potato Centre Ltd,Seed Potato Centre Ltd, MyllymäenPeruna Ltd, Finpom Ltd., Boreal Plant Breeding Ltd. and S. G. Nieminen Ltd (SGN Group). The agents co-operate with breeders. Agents pay the seed potato breeders royalties for the varieties they represent. Agents represent a specific variety that can only be cultivated by a marketing company or seed potato producer by agreement with the agent. There are also "free" varieties that can be cultivated without this kind of agreement. Seed potato producers and seed potato marketing companies operates mainly in the oligopolistic market. Companies that operate as agents on the market or under license from agents can also import seed potato or engage in higher-class basic seed production. (Tuomisto, 2007).

Figure 1 illustrates briefly the structure of the Finnish food potato supply chain. In Finland, a firm, independent farmer or private person interested in packing seed potato for marketing must apply for a permit from the Seed Certification Unit of the Finnish Food Authority. Only packing plants with proper authorisation are allowed to produce seed potato batches for inspection and certification, and only certified batches are allowed on the Finnish seed potato market. (Tuomisto, 2007). 


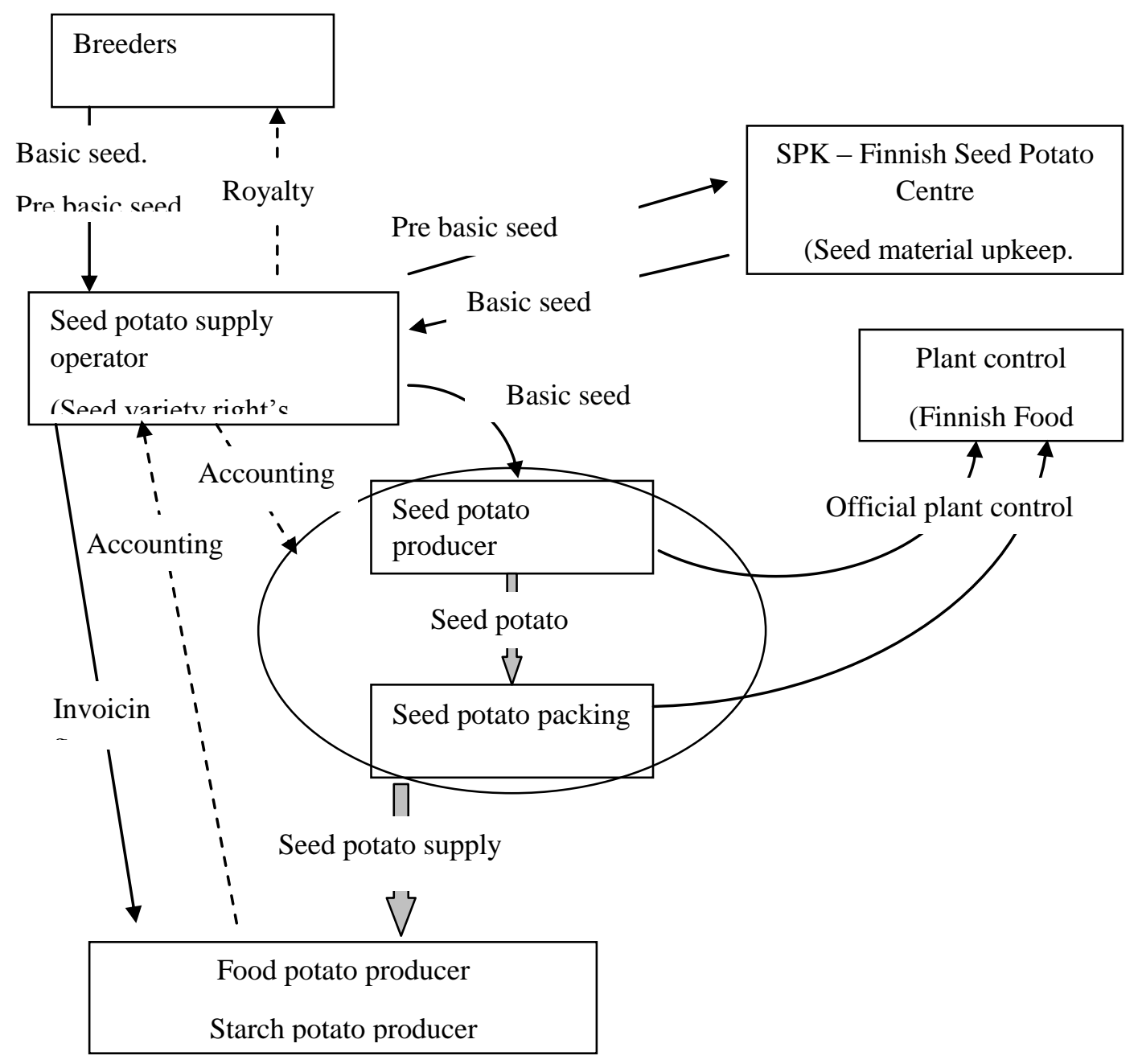

Figure 1. The vertical supply chain of the seed potato market (Tuomisto 2003)

Breeders use techniques based on the alteration of genetic traits to develop new potato varieties with agronomic characters and crop use values that meet the requirements of both the farmer and the crop user. The breeder co-operates with an agent. The breeder supplies the agent with genetic material either in test tubes or in the form of tubers, which are used by the SPK to produce basic seed, pre-basic seed or new micro-propagation (in vitro) material.

The breeder can also directly supply the agent with basic seed, which the agent can forward to contract producers for the production of certified food potato seed. Seed potato producers and packing plants will most often work in close cooperation with agents and seed potato marketing companies to supply food potato producers with seed which has been prepared, packed and inspected bythe Finnish Food Authority, although invoicing will be handled through a marketing company. The marketing company pays the seed potato fees either to the packing plant or directly to the seed potato producer. Starch potato production and food industrial potato production operate in the contract production but food potato production operates in the full competition market in Finland.

\section{The implications of adopting gene technology in the Finnish potato market}

Finnish potato market experts do not see the introduction of genetically modified varieties of potato affecting the potato chain to any large extent. However, interviews showed that at this point it remains relatively uncertain what specific impact GM technology will have on Finnish potato chain and on Finnish agri-food chain in general, for that matter. Because both the efficacy and the price of GM potatoes are still unknown, it is difficult to make a quantitative assessment of the socio-economic impacts of this new technology. 
There is a notable lack of examples, meaning that there are no points of comparison in Finland. It is difficult to apply practical experience from the United States to Finnish circumstances. Furthermore, the debate on gene technology in the EU has been coloured by strong denial, and it is considered unlikely that the technology will be adopted in the near future. On the other hand, interviewees saw the introduction of gene technology as inevitable in the long term.

GM potatoes would generally give rise to two kinds of costs in the Finnish agri-food chain. First, royalties and breeders' license fees would fall on both farmers and agents. Secondly, there are the expenses of segregation, which are usually distributed along the entire chain. Interviewees also brought up the costs of analysis, which are handled by the authorities. Although farmers are responsible for the payment of royalties and breeders' license fees, it would seem that they also enjoy the most tangible benefits. Larger crops, better control over plant diseases and easier farming were seen as typical benefits that first wave products brought with them. The interviewees saw, unsurprisingly, that breeders would probably benefit most from second wave products. Breeders also saw second wave products as more interesting in an economical sense than first wave products.

It is not expected that GM potatoes would affect the overall structure of the potato market chain, nor that the adoption of GM potatoes would speed up the increased concentration of the chain in the short run. It is also thought unlikely that any single GM product would become commercially successful enough to introduce new participants into the chain.

Overall, it is believed that the introduction of GM potatoes would seem to burden all parts of the potato chain evenly, making it difficult to identify actual winners and losers. Most of the burden, however, would seem to land on the authorities. The definition, testing and controlling of GM varieties is left to the authorities, and interviewees generally saw questions of control as one of the most difficult. The situation is by no means made easier by the fact that, internationally, there are deficiencies in e.g. the rules governing seed testing and analysis.

Most experts see the segregation of GM and non-GM material as the most difficult issue in the process of introducing GM potatoes. This conclusion is very similar to the results of research carried outside Finland. The segregation and identity preservation, which begins at the farm level from isolated storage to different transportation systems - requires that the entire value-chain be co-ordinated in order to preserve the value trait in a potato until it reaches the consumer. This situation, in turn, raises a range of positive as well as normative questions. Who should pay the costs in the absence of intervention? The answers will depend on a range of factors, notably the level of consumer demand for GM products, the availability of viable substitutes, and the strategy play between the various players along the chain.

According to the interviewees, maintaining two products in the same chain will prove expensive, causing one or other of the products in the chain to disappear from the market. A system of three chains is only seen as an intermediate stage in a development toward only two chains (GMO and organic farming). Interviewees see Finland as an unlikely candidate for a GM-free zone, since imports cannot be stopped completely.

Interviewees also see the segregation of GM and non-GM products as a very difficult task if the goal is total separation. In practice, segregation may involve meticulous cleaning of farming equipment, focusing entirely on a specific variety of plant or limiting cultivation to a certain section of farmland. Wintering caused by warming of the climate may pose additional problems. When new seed potato is being planted, old seed potato may already be present in the soil, making separation extremely difficult. This problem is very prominent in Southern Finland. Wintering takes place during mild winters with early snowfall, but only approximately once in ten years' time (Kuisma, 2005; Tuomisto and Huitu, 2006; Mustonen, 2007). Tubers that remain underground after the harvest can be better exposed for destruction by night-time frost in the autumn by harrowing the surface after harvest at a depth of 5-7 cm. Repeated harrowing after a few frosty nights assures that the residual potatoes are destroyed by frost. Preceding crop restrictions can also avoid residual vegetation problems (Kuisma, 2005).

Interviewees believe that the segregation of GM and non-GM seed potato varieties will not pose a problem, with the clear separation of material that has been achieved. Additional costs might crop up, however, if the authorities were to demand separate warehousing, for example. The potato chain from the seed potato onward is less easily manageable, making mix-ups more likely.

Logistic arrangements can pose a great challenge in Finland if the networking of food production causes segregation and the need for tracking products to the original farm to become mandatory. The arrangement of transportation alone in a scarcely populated country such as Finland will be a challenge, and transport costs may increase the prices of end products. The construction of separate warehousing is a costly operation, and separate harvesting and grading procedures for modified and non-modified product are difficult to implement. The situation in Finland is not optimal in the sense that the growing of certain varieties is not concentrated on a single area, as is the case in the United States, but usually rather fragmented. 
In terms of logistics, the transportation of GM varieties may prove expensive, e.g. in the case of handling GM varieties in separate truckloads. On the other hand, expensive logistic solutions are an everyday reality in Finland with the volume of special and organically grown plant varieties very small compared to the high costs of logistics. In addition, retailers demand small volumes of several different varieties of potatoes, which in itself lead to an increase in logistical costs.

Experts interviewed for the study see the controlling of GM varieties in the Finnish agri-food chain as feasible. However, the controlling of imports is seen as very challenging. In the case of potatoes, at least seed and end products are being imported. Though is very unlikely that there would be an influx of GM material from abroad, the risk is nevertheless there. The risks of importing are relatively low in the case of the potato because of well-enforced import regulations (partly due to diseases). The "hunting down" of GM seed is considered a moderately difficult task. The most problematic issue is potato cultivation on domestic patches and the implementation of internal seed regeneration on the farm. Unintentional transportation of seed material may then take place from the domestic-use patches (Tuomisto, 2005)

Experts find that the introduction of a GM potato variety would not change the relationship between agent and contract seed potato producer because the processes and costs of production would remain relatively unchanged. Yet, they believe that if a potato-farming contractor owned exclusive rights to a certain special variety, farming contracts might become more restricting. This would happen, primarily, to stop the potato from falling into competitors' hands. More restricting contracts would be sought in order to stop farmers from selling their crop to the highest bidder, therefore accentuating the importance of contractual obligations. The relationship between agent and breeder will be affected significantly by the advent of GM varieties. Experts believe that royalties, in particular, will increase. In addition, breeders will want to be sure that their product does not end up in the wrong hands. This will cause agreements to become even more restrictive, eroding a tradition of farmer independence in production decisions and management.

On the other hand, the introduction of GM varieties would help growers specialise, leading to the disappearance of multipurpose farms. Restrictive contracts are also likely to offer greater access to new technology and inputs, and new sources of capital. Official requirements for cultivation might also tighten, but rather on the side of the authorities and not the agents. These official requirements may cause an increase in costs, but from the outside rather than from the process of growing itself.

It is also expected that vertical integration and co-ordination between potato producers and processors that are designed to achieve improved alignment and control across segments of the production and marketing system will increase due in part to advances in biotechnology. Both supply and demand factors underlie the trend toward vertical integration. While vertical integration could reduce competition in the potato sector, it could also improve marketing efficiency and lower the cost of processing potatoes.

\section{Conclusions}

This paper has analysed the possible adoption and commercial introduction of genetically modified (GM) crops within selected agri-food markets in Finland. In order to provide further insights into the economic and strategic issues plus the implications of adopting GM technology in the Finnish agri-food chain, a case study on potato has been carried out. The study suggests as far as potato is concerned that there seems to be little empirical support for the view that large farms in good agricultural regions can make better use of the GM technology than small farms in remote areas. The study also claims that GM technology will not alter the basic structure of agri-food industry, but will create changes in the cost and benefit distribution. In addition, an increased use of contractual arrangements will lead to greater vertical integration and co-ordination in the value chain of potato.

\section{References}

Bullock, D. \&Nitsi, E. (2001). Roundup Ready Soybean Technology and Farm Production Costs: Measuring the Incentive to Adopt. American Behavioural Scientist, 44, 1283-1301.

Brookes, G. \& Barfoot P. (2017). Farm income and production impacts of using GM crop technology 1996-2015. GM crops \& food 2017:8(3):156-193. doi:10.1080/21645698.2017.1317919.

Desquilbet, M. \&Lemarie, S. \&Levert, F. (2002)."Potential Adoption of Genetically Modified Rapeseed in France, Effects on Revenues of Farmers and Upstream Companies: an ex ante evaluation," 2002 International Congress, August 28-31, 2002, Zaragoza, Spain 24975, European Association of Agricultural Economists. Available: https://ideas.repec.org/p/ags/eaae02/24975.html 
Eriksson, D., Brinch-Pedersena, H., Chawadea, A., Holmeb, I, Hvoslef-Eidec, T., Ritala, A., Teeri, T. and Thorstensenf, T. (2018).Scandinavian perspectives on plant gene technology, applications, policies and progress.PhysiologiaPlantarum 162: 219-238. 2018

Guenthner, J.F. (2017). Economic and environmental benefits of biotech potatoes with traits for bruise resistance, late blight resistance, and cold storage. AgBioForum, 20(1), 37-45. Available: http://www.agbioforum.org.

Hillyer, G. (1999). Biotechnology Offers U. S. Farmers Promises and Problems. AgBioForum 2, 99-102. Available: http//www.agbioforum.org.

Kathage, J., Rodríguez-Cerezo, E., \& Gómez-Barbero, M. (2016).Providing a framework for the analysis of the cultivation of genetically modified crops: The first Reference Document of the European GMO socioeconomics bureau.AgBioForum, 19(2), 112-119. Available: http://www.agbioforum.org.

Kinnucan, H, Upton, H., Molnar J. and Venkateswaran (1990). Scale Neutrality of Bovin Somatotropin: Ex-ante Evidence from Southeast. Southeastern Journal of Agricultural Economics 1990, 1-12.

Ministry of Agriculture and Forestry of Finland (2019).Genetically modified and novel foods.Available: https://mmm.fi/en/food-and-agriculture/food/genetically-modified-and-novel-foods

Mustonen, L., Peltonen-Sainio, P., Pahkala, K. (2008). Perunan GM-lajikkeiden jääntimukulat - riski geeniaineksen siirtymisestä.[Voluntary tubers of GM-potatoes - risk for the gene flow] In: Toim. Leena RantamäkiLahtinen. Maataloustieteen Päivät 2008 10.-11.1.2008, Viikki, Helsinki : esitelmä- ja posteritiivistelmät. Suomenmaataloustieteellisenseurantiedote 24: p. 21.

Niemi, J. \&Virolainen, M. (2002). Ex-ante Economic Assessment of Adopting Genetically Engineered Crops in Finland.In V. Santaniello, R.E. Evenson and D. Zilberman (Eds.).Market Development for Genetically Modified Food(pp. 159-166). Wallingford, UK: CABI Publishing.

Punt, M., Venus, T.J., \&Wesseler, J. (2017). The costs of coexistence on farms in Germany.AgBioForum, 20(1), 24-36. Available: http://www.agbioforum.org.

Salo, A., Kauppinen, V. and Rask, M. (1998). Loppuraportti kasvitekniikasta: Kasvigeenitekniikka ravinnontuotannossa.[Abstract: Plant gene technology in food production]. Committee for the future, Parliament of Finland, publications 1998/4 (199 p). Helsinki: Parliament of Finland.

Tuomisto, J. (2003).

SiemenperunansopimustuotantoSuomessa.Sopimustuotantosiemenperunanmarkkinaepävarmuudestaaiheutuvanh yvinvointitappionalentajana [Abstract: Contracting in the Finnish Seed Potato Market, Contract Production as a Method to Reduce Welfare Loss Caused by Market Uncertainty of Seed Potato]. MTT Agrifood Research Reports 22 (109 p), 17 appendices. Helsinki: MTT Agrifood Research.

Tuomisto, J. (2004). Benefits and costs of the first wave of gene technology: A case study on potato in Finland. Paper presented at the 8th International ICABR Conference, Ravello, Italy.

Tuomisto, J. (2005). Co-existence of GM and non-GM potato varieties on Finnish potato farms - Potential costs and remedies. Paper prepared for the 9th ICABR International Conference on Agricultural Biotechnology: Ten Years Later. Ravello, Italy, July 6 - 11, 2005. Available: http://www.economia.uniroma2.it/ conferenze/ icabr2005/abstract.

Tuomisto, J. and Huitu, H. (2006). Reducing costs caused by isolation requirements between GM and non-GM potato fields - a method based on GIS. In: 10th ICABR International Conference on Agricultural Biotechnology : Facts, Analysis and Policies, June 29 - July 2, 2006. Ravello, Italy. 2 p. (Abstract). Available: http://www.economia.uniroma2.it/conferenze/icabr2006/

Tuomisto, J. (2007). Contract production as a method to reduce welfare loss caused by market uncertainty of seed potato.Agricultural and food science 16, 1:3-16.

Virolainen, M. and Niemi, J. (2000).

GeenitekniikanjamuuntogeenisenruuantaloudellisetvaikutuksetSuomenelintarvikeketjussa [Abstract: Economic effects of genetic engineering and genetically modified food in the Finnish food sector]. Agricultural Economics Research Institute (AERI), Working papers 7/2000 (53 p). Finland. Helsinki: AERI. 